\title{
Rozwój i zainteresowania badawcze chorwackiej frazeologii
}

Frazeologia jako dziedzina badań językoznawczych pojawiła się w Chorwacji stosunkowo późno, bo na początku lat siedemdziesiątych XX wieku, co nie znaczy, że wcześniej nie dostrzegano potrzeby tego rodzaju badań. O zwracaniu uwagi przez badaczy języka na jednostki frazeologiczne różnego typu świadczy zamieszczanie ich i próby klasyfikacji w najdawniejszych słownikach i leksykonach języka chorwackiego od XVII wieku. Ówcześni autorzy tych prac mieli świadomość „wyjątkowości” tych konstrukcji, większych od pojedynczego leksemu, a mniejszych od tekstu, które często same w sobie stanowiły pewien mikrotekst, charakteryzujący się trafnością osądu i oceny rzeczywistości oraz wynikającą stąd popularnością, powtarzalnością.

Zainteresowanie szeroko rozumianymi związkami frazeologicznymi w kulturze europejskiej miało swój początek już w średniowieczu, kiedy to około 1500 r. pojawił się zbiór niepodzielnych związków wyrazowych (przysłowia, powiedzenia, zwroty używane często w języku lub literaturze) autorstwa Erazma z Rotterdamu (Filaković 2008, 38). Idąc za tym przykładem, w następnych wiekach wzrastało zainteresowanie przysłowiami i powiedzeniami, sentencjami, dając wkrótce początek nauce zwanej z greckiego paroimologia, zajmującej się w ramach badania folkloru zbieraniem narodowych przysłów, jednostek, które dziś włączane są do szeroko rozumianych badań frazeologicznych. Rozwój frazeologii jako samodzielnej dyscypliny naukowej rozpoczął się dość późno, 
bo na początku XX wieku i miał wyraźny związek ze strukturalizmem. Kojarzony jest z nazwiskiem ucznia Ferdynanda de Saussure’a - Charlesa Bally'ego, który stworzył teoretyczne podstawy frazeologii synchronicznej, jest też autorem nazwy tej dyscypliny nauki, który to termin na początku się nie przyjął. W 1909 r. wydał Traktat o gramatyce francuskiej, w którym próbował opisać w sposób naukowy jednostki frazeologiczne, lokując je w obrębie stylistyki. Zauważył on tendencję do łączenia się pewnych określeń, grup wyrazów z innymi wyrazami, a połączenia te charakteryzują się zwiększoną frekwencją. Dokonał klasycznego już, prototypowego podziału związków frazeologicznych na połączenia całkowicie scalone, o znaczeniu globalnym, nie wynikającym z sumy znaczeń składników, np.: biały kruk 'rzadkość, okaz bibliofilski', oraz na połączenia zmetaforyzowane, w których jeden z komponentów zachowuje znaczenie podstawowe, drugi zaś zyskuje znaczenie przenośne, dzięki czemu całość ma charakter metaforyczny, np.: czarna rozpacz 'wielka, straszna rozpacz' (EJO 1995, 162-163).

Rozwój frazeologii, jako samodzielnej dyscypliny naukowej, związanej jednakże dość ściśle z leksykologią, wiąże się z pracami badawczymi rosyjskiej szkoły językoznawczej w połowie XX wieku, głównie V.V. Vinogradova - Osnovnyje ponijatija russkoj frazeologii kak lingvističeskoj discipliny (1946), Ob osnovnych tipach frazeologičeskich edinic v russkom jazyke (1947). Zasługą tego naukowca jest stworzenie metodologii badań frazeologizmów w oparciu o relacje i stopień łączliwości składników, a także zapoczątkowanie kierunku takiej frazeologii, w której centrum znajduje się wyraz w określonym otoczeniu syntaktycznym i stylistycznym (Jóźwiak-Dądela 2006, 18). Osiągnięcia Vinogradova i innych przedstawicieli szkoły rosyjskiej - V. Archangielski, A. Kunin, N. Šanskij, J. Melčuk, M. Molotkov - szybko rozprzestrzeniły się i znalazły zwolenników w pozostałych krajach słowiańskich. W Polsce byli to S. Skorupka, F. Pepłowski, D. Buttler.

Do Chorwacji pierwsze informacje na temat osiągnięć i teorii frazeologicznych rosyjskich językoznawców dotarły z pewnym opóźnieniem, bo na początku lat 70. XX wieku głównie za pośrednictwem chorwackich rusycystów językoznawców z ośrodka w Zagrzebiu skupionych wokół Anticy Menac. Jak widać, jest to więc dziedzina badań stosunkowo młoda, jej rozwój jednakże przebiega dość intensywnie, zwłaszcza w początkowym okresie, jak i w ciągu ostatnich kilkunastu lat (od połowy lat 90. XX w.). Na szczególną uwagę i przybliżenie zasługuje osoba prekursorki badań frazeologicznych w Chorwacji - prof. Anticy Menac, która skupiła wokół siebie grupę badaczy, tworząc podwaliny pod powstanie Zagrzebskiej Szkoły Frazeologicznej (Zagrebačka frazeološka škola), początkowo skupiającej głównie rusycystów (Ž. Fink-Arsovski), z czasem 
obejmującej coraz szersze kręgi i grupującej naukowców innych specjalności filologicznych. Szkoła ta nadal prężnie działa i może poszczycić się kolejną generacją badaczy frazeologii na różnych obszarach i w różnych językach (A. Hrnjak, I. Vidović-Bolt, M. Menac-Mihalić, N. Vajs, V.Zečević, S. Zubčić, M. Opašić, B. Kovačević).

Wielu badaczy za symboliczną datę narodzin frazeologii chorwackiej uważa wydanie artykułu A. Menac w czasopiśmie „Jezik” (rocznik 18, zeszyt 1, 1970/71.) zatytułowanego O strukturi frazeologizama. Jest to pierwsza, dość zwięzła publikacja naukowa poświęcona frazeologii na ziemiach chorwackich (Vidović-Bolt 2006, 825; Opašić 2011, 188). Autorka już w pierwszych zdaniach artykułu prezentuje trafną i obrazową definicję oraz charakterystykę frazeologizmu, którą w kolejnych publikacjach rozwija:

„Struktura frazeologizama je veoma čvrsta. Oni se reproduciraju u unaprijed određenom, gotovom obliku, tj. ne formiraju se svaki put iznova slaganjem pojedinih riječi, kao što se formiraju svobodne sveze riječi. Zbog takve čvrstine strukture frazeologizama njihovi se dijelovi obično i ne osijećaju kao riječi sa samostalnim značenjem, te značenje cijelog frazeologizma ne proistiječe iz značenja pojedinih dijelova" (Menac 1970, 1).

A. Menac zwraca uwagę na podstawowe cechy i elementy związku frazeologicznego, takie jak: ustaloną strukturę, desemantyzację elementów, całościowość semantyczną wyrażenia, jak również możliwość wariantywności pewnych składników, jednakże bardzo ograniczoną. Kolejne artykuły chorwackiej językoznawczyni rozwijają wcześniej nakreślone teorie, które stara się dostosować do warunków języka chorwackiego w niełatwym dla niego okresie dziejowym (wspólny idiom językowy chorwacko-serbski, problemy wynikające $\mathrm{z}$ różnorodności materiału dialektycznego na terenach chorwackich).

Prace językoznawcze A. Menac charakteryzuje wielopłaszczyznowość, szerokość zainteresowań w obrębie frazeologii, co jest typowe dla wczesnych badań $\mathrm{w}$ tej dziedzinie. Językoznawczyni w pierwszym okresie badawczym zajmuje się głównie problematyką metodologiczno-klasyfikacyjną, teorią frazeologii, by potem pójść w kierunku badań praktycznych. Mam tu na myśli prace leksykograficzne A. Menac w ramach projektu: Mali frazeološki rječnici w latach 80. Pod redakcją A. Menac wyszedł najpierw Rusko-hrvatski ili srpski rječnik (1980), a potem cała seria dwu- lub trójjęzycznych słowników frazeologicznych, wiele z nich również współautorstwa wyżej wymienionej językoznawczyni: Menac, Pintarić, Hrvatskosrpsko-poljski frazeološki rječnik; Menac, Vučetić, Hvatskosrpsko-talijanski frazeološki rječnik; Menac, Sesar, Kuchar, Hrvatsko-češko-slovački rječnik i inne. Dwadzieścia lat później autorka wspólnie z Željką Fink-Arsovski i R. Venturinem wydaje pierwszy jednojęzyczny frazeologiczny 
słownik języka chorwackiego - Hrvatski frazeološki rječnik (2003). Dowodem wszechstronności zainteresowań badawczych prof. A. Menac w dziedzinie frazeologii jest wydana w 2007 r. monografia prac autorki zatytułowana Hrvatska frazeologija, będąca zbiorem artykułów opublikowanych w latach 1970-2005. Publikacje tam zebrane dotyczą sfery metodologii badań frazeologicznych, frazeologii porównawczej (w obrębie języka rosyjskiego głównie, ale nie tylko, także włoskiego, niemieckiego, angielskiego, francuskiego), zapożyczeń, kalk frazeologicznych, frazeologii historycznej - obecności frazeologizmów w starszych słownikach i dawnej literaturze chorwackiej (Gundulić, Hektorović, Mažuranić), z czym wiążą się także badania w obrębie frazeologii dialektalnej - głównie dialektów czakawskich. Autorka kończy rozważania refleksjami nad współczesnym stanem badań frazeologicznych, przedmiotem ich zainteresowań, sposobami wzbogacania współczesnego zasobu frazeologizmów, omawia zapożyczania z innych języków, dialektów, socjolektów, języka mediów. Monografia stanowi swoiste ukoronowanie bogatej działalności naukowej A. Menac, będąc jednocześnie, zdaniem Ž. Fink-Arsovski, historią rozwoju chorwackiej frazeologii od jej początków do dziś (Fink-Arsovski 2007, 231).

Innymi językoznawcami, wielce zasłużonymi dla rozwoju badań w dziedzinie frazeologii we wczesnym okresie jej rozwoju, jak i obecnie są Josip Matešić i Željka Fink-Arsovski. Wespół z wyżej przedstawioną A. Menac tworzą oni, zdaniem M. Opašić, „wielką trójkę” chorwackiej frazeologii. J. Matešić jest autorem największego i zarazem pierwszego na ziemiach chorwackich słownika frazeologicznego - Frazeološki rječnik hrvatskoga ili srpskoga jezika (1982), choć, co typowe dla czasów, w jakich powstał, z dość znaczną ilością materiału serbskiego. Matešić jest też autorem wielu publikacji w dziedzinie frazeologii, zwłaszcza dialektalnej. Ž. Fink-Arsovski - zagrzebska rusycystka, jest niestrudzoną kontynuatorką badań językoznawczych A. Menac, na niwie teoretycznej, w dziedzinie komparatystyki frazeologicznej, czego dowodzą liczne artykuły i obszerna monografia: Poredbena frazeologija - pogled izvana i iznutra (2002). Niezwykle cennymi osiągnięciami lingwistki są jej prace leksykograficzne - wymieniony już Hrvatski frazeološki rječnik (2003) oraz obszerny i bogaty w materiał z dziewięciu języków słowiańskich Hrvatsko-slavenski rječnik poredbenih frazema (2006). Ž. Fink jest ponadto współautorką opracowanej razem z B. Kovačević i A. Hrnjak bibliografii frazeologii chorwackiej wraz z indeksem frazemów (wydanie na płycie CD; 2010).

Wyżej wymienieni językoznawcy tworząc podwaliny pod powstanie chorwackiej frazeologii, jednocześnie wykształcili liczną grupę następców, między innymi rekrutujących się z szeregów wspomnianej Zagrzebskiej Szkoły Frazeologicznej. Podejmują oni badania na różnych polach i płaszczyznach: teoretyczno- 
-metodologicznej, kontrastywnej, historycznej, dialektycznej, kognitywnej, w dziedzinie języka mediów. Dla nowszych badań frazeologicznych charakterystyczna jest większa niż wcześniej specjalizacja badawcza, dotyczy to zwłaszcza najnowszych prac powstałych po 2000 roku. Od połowy lat 90 . XX w. zaobserwować można swoisty renesans badań frazeologicznych w Chorwacji, co ma zapewne związek ze zmianami politycznymi, które sprzyjają badaniom językowym, są bodźcem do tworzenia nowych projektów, zwłaszcza leksykograficznych.

Celem rozważań jest zwrócenie uwagi na kilka aspektów, obecnych w ciągu ponadczterdziestoletniego okresu kształtowania się, formowania chorwackiej tradycji badań frazeologicznych, ze szczególnym uwzględnieniem ostatnich kilkunastu lat, kiedy to badania te nabierają tempa, pojawiają się nowe tendencje i zainteresowania. Analizując teksty naukowe poświęcone problematyce frazeologicznej, można wyodrębnić kilka kluczowych dla tej dziedziny zagadnień i aspektów badawczych: 1. problemy terminologiczne i metodologiczno-klasyfikacyjne, 2. frazeologia dialektalna, 3. frazeologia historyczna, 4. frazeologia porównawcza, 5. kognitywne aspekty frazeologii, 6. działalność leksykograficzna.

Problemy terminologiczne i metodologiczno-klasyfikacyjne. W pierwszych tekstach naukowych poświęconych frazeologii chorwackiej występuje pojęcie frazeologizam na określenie ustalonego związku wyrazów, o całościowym, globalnym znaczeniu, termin ten pojawia się we wczesnych pracach A. Menac, z czasem jednak zastępują go inne terminy: frazem, fraza, idiom, izričaj, idiomatička fraza, frazeološka jedinica, lokucija. Ich zakres znaczeniowy nie jest do końca tożsamy, niemniej jednak często używane są wymiennie. Obecnie najbardziej rozpowszechnionym terminem jest frazem, który zupełnie zdominował pozostałe określenia, zarzucono też wcześniej używany termin: frazeologizam, zachowując jednakże formy derywatów: frazeologija, frazeološki. Termin frazem utworzony został wzorem ustalonych już terminów lingwistycznych, takich jak morfem, fonem, leksem. Na początku nie był on entuzjastycznie przyjęty przez wszystkich językoznawców, krytykuje go m.in. J. Matešić, widząc w nim niepotrzebne i mylące analogie właśnie z podobnymi terminami. Z kolei D. Sesar $(1998,307)$ opowiada się za użyciem terminu frazem, wyjaśniając, że „frazeologizm jest przejęty z językoznawstwa rosyjskiego i nie odpowiada analogicznym określeniom, jak: fonologia - fonem, w takiej postaci jest więc nieodpowiedni i nieograniczony" (Vidović Bolt 2006, 836). Odpowiednikiem chorwackiego pojęcia frazem w polskiej tradycji językoznawczej jest frazeologizm, związek frazeologiczny. Wprawdzie i u nas znane jest też i stosowane pojęcie frazem, które zostało wprowadzone przez Wojciecha Chlebdę, ale jego zakres znaczeniowy jest szerszy, nie jest też terminem 
ogólnie przyjętym i uznawanym przez wszystkich językoznawców. W. Chlebda stosując go, pragnął w nim widzieć: „hiperonim obejmujący całe spektrum ustabilizowanych wielowyrazowych jednostek języka, takich jak frazeologizmy, terminy złożone, przysłowia, skrzydlate słowa, wyrażenia funkcyjne, operatory pragmatyczne" (Chlebda 1991, 19). Tymczasem, jak zauważył autor, termin ten zaczął być używany obok określenia frazeologizm, a nawet w opozycji do niego, terminem frazeologizm określano typowe, klasyczne przykłady jednostek frazeologicznych, a frazem miał mieścić w sobie niestandardowe, nie zawierające się w nim konstrukcje (Nowakowska 2005, 21).

Jeśli chodzi o klasyczne definicje frazeologizmu, warto przytoczyć dwie z nich autorstwa nestorów chorwackiej frazeologii - Anticy Menac i Josipa Matešicia. Obie wzajemnie się uzupełniają, choć pewne różnice w podejściu do tego, co można uznać za frazeologizm, są tu zauważalne:

„[frazemi] su ustaljene sveze riječi koje se upoterbljavaju u gotovu obliku, ne stvaraju se u tijeku govornog procesa, i kod njih je bar jedna sastavnica promijenila značenje, tako da značenje frazema ne odgovara zbroju značenja njihovih sastavnica" (Menac 2003, 6);

zaś według Matešicia związki frazeologiczne to:

„jedinice jezika značenjskog karaktera, koje se kao cjelina reproduciraju u govornom aktu raspolažujuci pri tome najmanje dvjema punoznačnim (autosemantičkim) rječima, od kojih barem jedna upućuje na semantičku pretvorbu, jedinice koje, zbog sposobnosti uklapanja u kontekst, poput svake druge riječi, mogu vršiti sintaktičku funkciju u rečenici” (Matešić 1982, VI).

Widać na podstawie tych definicji różnicę w traktowaniu składników związku frazeologicznego. Według Matešicia mogą go tworzyć co najmniej dwa autosemantyczne, samodzielne elementy, nie uznaje on połączeń wyrażeń przyimkowych, enklitycznych lub proklitycznych wyrażeń typu: preko volje, bez riječi (tzw. fonetske riječi), Menac, Fink-Arsovski zaliczają te formacje do frazeologizmów i zamieszczają w swym słowniku.

Na podstawie obu definicji można ustalić najważniejsze cechy związku frazeologicznego:

1. stałość, niepodzielność konstrukcji - związek funkcjonuje składniowo i znaczeniowo jako całość;

2. odtwarzalność, powtarzalność wynikająca z długiej tradycji użytkowania;

3. idiomatyczność - znaczenie frazeologizmu nie jest sumą znaczeń składników;

4. kontekstowość - frazeologizm jako element wbudowujący się w kontekst i strukturę składniową zdania, pełniący w nim określoną funkcję syntaktyczną. 
Wiele kontrowersji budzi struktura związku frazeologicznego, charakter jego elementów składowych, na podstawie których wyodrębniono trzy kategorie frazeologizmów:

1. fonetska riječ - jest to zazwyczaj wyrażenie przyimkowe bądź pojedyncze autosemantyczne wyrażenie $z$ enklityką lub proklityką, które charakteryzuje się pewną stałością, powszechnością użycia: bez riječi, za mahove, preko volje, za čas, niz dlaku. Nie ma pełnej zgodności co do zaliczania tych formacji do frazeologizmów (odmawiają im tego m.in. Matešić, Samardžija), ale obecnie większość językoznawców widzi dla tych konstrukcji miejsce, zwłaszcza w tzw. szerokim ujęciu związku frazeologicznego.

2. skup riječi - związek wyrazowy, syntagma, najbardziej rozpowszechniony rodzaj frazeologizmu, składający się z dwu lub więcej wyrazów autosemantycznych, które wbudowując się w zdanie, pełnią w nim określoną funkcję składniową, przy czym stopień desemantyzacji może być tu różny. Ze względu na główny element konstruktywny związku wyróżniamy między innymi frazemy: rzeczownikowe: bijeli dan, crne misli, daleki svijet, anđeo čuvar; przymiotnikowe: jedan te isti, crn kao gavran, škrt na riječima; czasownikowe: biti tvrde glave, pasti komu na pamet i inne. Ten rodzaj związków frazeologicznych zazwyczaj nie budzi kontrowersji, są to tzw. pravi frazemi, które składniowo i semantycznie spełniają warunki stawiane tego rodzaju konstrukcjom.

3. rečenica - fraza - związek frazeologiczny mający postać zdania mniej lub bardziej rozbudowanego: čekati koga kao ozebao sunca, biti svakom loncu poklopac, staviti kome buhu u uho. Do tej grupy, oprócz typowych frazeologizmów zaliczyć można także, $\mathrm{z}$ dużą dozą tolerancji: przysłowia, powiedzenia, porzekadła, „skrzydlate słowa”. Nie ma w tej kwestii pełnej zgodności wśród językoznawców. Nie widzą przysłów wśród frazeologizmów m.in. Z. Fink-Arsovski, A. Menac (nie zamieszczają ich w swym ostatnim słowniku frazeologicznym z 2003 r.), z kolei w innych opracowaniach traktuje się przysłowia jako najviše istraživanu i dosada najiscrpnije obrađenu frazeološku vrstu (Matulina 2005, 67).

${ }^{1}$ W polskiej tradycji frazeologicznej jednostki tego typu też nie są w sposób jednoznaczny zaliczane do frazeologizmów. Na pewno czyni to W. Chleb da, widząc dla nich miejsce wśród szeroko rozumianych frazemów, których głównym wyznacznikiem jest odtwarzalność. Inne określenia dla tego typu formacji, które można odnaleźć w pracach językoznawczych, to: wyrażenia funkcyjne (Grochowski), wskaźniki frazeologiczne (Lewicki, Pajdzińska), które pełnią funkcje pomocnicze w zdaniu. 
Jak widać, najwięcej kontrowersji wzbudzają granice - górna i dolna - określania danego związku mianem frazeologizmu, a są one natury semantycznej i syntaktycznej. Niebagatelną rolę odgrywa charakter składników (samodzielność lub niesamodzielność znaczeniowa, funkcje składniowe w zdaniu, stopień ekspresyjności, zmetaforyzowania, możliwość wariantywności elementów).

Próbą pogodzenia zróżnicowanych stanowisk jest kolejny, ogólnie przyjęty i bardzo często stosowany przez językoznawców chorwackich, podział frazeologizmów na: frazemi u užem smislu (pravi frazemi, idiomi, izričaji) - frazeologizmy w wąskim znaczeniu (rozumieniu) i frazemi u širem smislu (lokucije) - frazeologizmy w szerokim znaczeniu. Pewną analogię można odnaleźć w polskim językoznawstwie w prototypowym podziale frazeologizmów S. Skorupki na związki stałe - odpowiednik to frazemi u užem smislu; z kolei związki luźne i łączliwe w pewnym stopniu mogą odzwierciedlać strukturę frazema u širem smislu.

Frazemi u užem smislu - to związki wyrazowe, w których poszczególne elementy uległy zupełnej lub znacznej desemantyzacji, znaczenie całości związku nie jest sumą znaczeń elementów, nie są tworzone doraźnie, ale funkcjonują $\mathrm{w}$ języku jako formacje utrwalone dzięki tradycji długiego używania (Fink-Arsovski 2002, 6-7), mają one przeważnie formę związku wyrazów (syntagmy) lub frazy: mačji kašalj, kula od karata, duša od čovjeka, imati debelu kožu, i ovce i novce, pasti s konja na magarca, prošla baba s kolačima.

Frazemi u širem smislu - w przypadku tych konstrukcji znaczenie elementów nie uległo całkowitej desemantyzacji, często zachowany jest związek znaczeniowy z przynajmniej jednym z nich, choć są to także formacje w pewnym sensie gotowe, uschematyzowane w praktyce komunikacyjnej, zwraca się uwagę na mniejszy stopień metaforyzacji wyrażenia, stąd licznie tu występują terminy, wyrażenia w procesie frazeologizacji, skrzydlate słowa, powiedzenia i przysłowia: crno tržište, pranje novaca, sedam veličanstvenih, poduzeti potrebne mjere, dovesti u pitanje, okititi se olimpijskom medaljom, izvršiti isplatu.

Granice między tymi dwoma kategoriami też są płynne. Do wyodrębnienia podziału między formacjami o większym lub mniejszym stopniu idiomatyczności przyczynił się nie dający się jednoznacznie sklasyfikować typ tzw. porównań frazeologicznych - poredbeni frazemi, która to kategoria może posiadać znaczenie zleksykalizowane - zazwyczaj dotyczy to frazemów dwuczłonowych typu: kao + rzeczownik lub fraza: kao kec na jedanaest, kao bog, kao na iglama; może też wyrażać znaczenie nie w pełni zleksykalizowane, mające związek z którymś z elementów składowych wyrażenia: ići kao muha bez glave, pjevati kao slavuj, plakati kao malo dijete. Wiele $\mathrm{z}$ tych konstrukcji jest tworzonych doraźnie, ich liczba stale wzrasta, jest to niezwykle płodna i produktywna kategoria, dowodem na to są licznie tworzone słowniki 
frazeologizmów porównawczych w obrębie jednego bądź kilku języków, np.: Hrvatsko-slovenski rječnik poredbenih frazema Z. Fink-Arsovski.

W definiowaniu i klasyfikacji frazeologizmów w języku chorwackim istnieje wiele stanowisk, co przypomina ujęcie tego problemu w polskich badaniach językoznawczych. Warto w tym miejscu przytoczyć kilka opinii potwierdzających niejednoznaczność zjawiska frazeologizmów, jak i zróżnicowanie samej dyscypliny badawczej: „postoje velike razlike u definicijama što ih za frazeologizm daju pojedini autori” (Muhvić-Dimanovski 1992, 323); „nema jedinstvena mišljenja o tome što je frazem” (Matešić 1991, 309); „Nie ma jednej frazeologii, lub jeśli kto woli, frazeologia jest nauką wieloaspektową. Każda z odmian frazeologii zakłada inny sposób patrzenia na język i inne stawia sobie cele" (Lewicki 1974, 151).

Frazeologia dialektalna. Dialektologia jest dziedziną badań językoznawczych o znacznie bogatszej tradycji i osiągnięciach niż stosunkowo młoda dyscyplina, jaką jest frazeologia. Niemniej jednak połączenie tych dwu dyscyplin daje ciekawe i bogate efekty. O ważności badań dialektologicznych pod kątem frazeologii dla kultury, historii i współczesności języka chorwackiego przekonywał między innymi J. Matešić w artykule $O$ problemu dialektalne frazeologije (Matešić 1988, 53), akcentując niepodważalną doniosłość tradycji piśmienniczej czakawskiej, kajkawskiej i sztokawskiej w różnych okresach historii Chorwacji, jak również stałą, dalszą obecność tych dialektów oraz ich miejscowych odmian w praktyce komunikacyjnej. Ważne jest jednakże „ocalenie od zapomnienia” wielu miejscowych gwar, którym grozi wyginięcie, gdyż obecne są one często już tylko w folklorze, pieśniach i tu właśnie jest doniosła rola do spełnienia dla badań dialektologicznych.

W badaniach dialektalnych frazeologia zajmuje ważną pozycję, ponieważ słownictwo dialektalne, zazwyczaj nacechowane emocjonalnie, zawiera spory zasób związków frazeologicznych. Co interesujące, wiele z nich funkcjonuje w zbiorowej świadomości, w języku standardowym. Matešić wymienia tylko niektóre z nich: Martin u Zagreb, Martin iz Zagreba ma proweniencję lokalną z kajkawskiego Zagorja, kiedyś mogło być niezrozumiale np. dla rybaka z Dalmacji, dziś jest ogólnie znanym frazeologizmem. Inne lokalizmy, znane i rozumiane, choć nie zawsze przez najmłodsze pokolenie, to: praviti račun bez birtaša (krčmara), imati dunsta (pare), imati putra (maslaca) na glavi, zapapriti čorbu (juhu), tjerati kera (psa), pijan kao lojtra. Wiele z nich, nawet mimo używania i rozumienia przez znaczną część użytkowników języka, nie ma szans na znalezienie się w chorwackim słowniku frazeologicznym, ich miejsce jest w słownikach dialektalnej frazeologii, których potrzebę tworzenia Matešić dobitnie i wyraźnie podkreśla.

Plan ten znajduje realizację w pracach wielu chorwackich językoznawczyń specjalizujących się w badaniach frazeologii dialektalnej. Są to między innymi: 
Mira Menac-Mihalić, Sanja Vulić, Marija Turk, Sanja Bogović, Nada Vajs, Vesna Zečević, Jela Marešić. Badaniami tymi zajmują się głównie dwa ośrodki naukowe: w Zagrzebiu (publikacje w czasopiśmie „Filologija”) i w Rijece (czasopisma: „Fluminensia”, „Riječ”). Wśród chorwackich badań dialektalnych wiele uwagi poświęca się dialektowi czakawskiemu i jego licznym gwarom. Warto wspomnieć o wczesnych badaniach czakawskiej frazeologii A. Menac, która w 1991 r. wydała pracę na temat frazeologizmów w czakawskim utworze Ribanje i ribarsko prigovaranje XVI-wiecznego poety z Hvaru Petara Hektorovicia. Jest to jednak bardziej rozprawa historyczno-literacka niż z dziedziny frazeologii dialektalnej. W następnych latach A. Menac z M. Menac-Mihalić kontynuują badania w obrębie frazeologii czakawskiej, tym razem we współczesnej poezji z wyspy Brač (Menac, Menac-Mihalić 1997; 1998). Jednakże nadal były to opracowania frazeologizmów z języka literackiego różnych okresów czakawszczyzny, nie zaś żywego, mówionego dialektu. Początek tego typu badaniom w dziedzinie frazeologii dały prace M. Turk Frazeologija krčkog govora (1997), S. Bogović Frazeologija u čakavskim dijalektološkim rječnicima (1998), Frazeologija grobničkih govora (1994), S. Vulić - na temat czakawskich przysłów oraz obecności frazeologizmów w wydanych do tej pory słownikach gwar czakawskich - Blagdanska imena i frazemi oraz Metodologija uvrstavanja frazema u rječnike izvornih čakavskih govora (obie z 1997; por. Vulić 2003, 44-45).

Od połowy lat 90. do chwili obecnej można mówić o wielkim rozkwicie badań i projektów w dziedzinie dialektalnej frazeologii chorwackiej. Jednym z takich projektów jest realizowany przez kroatystów z Uniwersytetu w Zagrzebiu projekt naukowo-badawczy Istraživanje hrvatske dialektalne frazeologije pod kierunkiem prof. M. Menac-Mihalić przy współudziale J. Marešić, A. Frančić i M. Malnar. W projekt zaangażowanych jest wielu pracowników naukowych oraz studentów. Rezultaty projektu to między innymi monografie (M. Menac-Mihalić, Frazeologija novoštokavskih ikavskih govora u Hrvatskoj (s rječnikom frazema i značenijskim kazalom s popisom sinonimnih frazema), Zagreb 2005 - zawiera ponad 4000 związków frazeologicznych z 14 nowosztokawskich dialektów ikawskich; M. Menac-Mihalić i J. Marešić, Frazeologija križevačko-podravskih kajkavskih govora s rječnicima, Zagreb 2008, w której zawarto około 3000 frazemów z 8 dialektów kajkawskich; M. Menac-Mihalić, A. Menac, Frazeologija splitskog govora s rječnicima, Zagreb 2011). W ramach projektu powstało też wiele artykułów, rozdziałów w monografiach naukowych, dysertacje doktorskie i magisterskie ${ }^{2}$. Badania dotyczą różnych gwar miejscowych występujących

2 Pełny i aktualny spis rezultatów badawczych w ramach projektu znaleźć można na stronie internetowej: http://bib.irb.hr/lista-radova?projekt=130-2120920-0838 (dostęp: 17.03.2013). 
w obrębie dialektów czakawskiego, kajkawskiego oraz sztokawskiego, mają one charakter terenowy, obserwacji uczestniczącej i co najważniejsze, pokazują aktualny stan dialektów chorwackich, analizowany pod szerokim kątem badawczym (fonetycznym, morfologicznym, etymologicznym).

Spośród rozlicznych publikacji na szczególną uwagę zasługują: M. Malnar, Somatska frazeologija čabarskih govora (Malnar 2011, 101-119), w której autorka przyjęła tematyczny aspekt analizy frazeologizmów z wybranego terytorium dialektu kajkawskiego, opracowując bogatą grupę frazemów somatycznych pod kątem ich klasyfikacji, przemian fonetyczno-morfologicznych, semantyki oraz pól znaczeniowych określonych części ciała; obszerna praca M. Matešić, Frazeologija mjesnog govora Vrbovskog (Matešić 2006, 37-81) dotyczy ikawsko-ekawskiego dialektu czakawskiego (Gorski Kotar). Ciekawy jest aspekt badawczy, jaki przyjęła autorka. Jest to analiza konceptualno-kognitywna, rzadko stosowana w odniesieniu do materiału dialektycznego, lecz bardzo charakterystyczna dla nowszych badań chorwackiej frazeologii. Za punkt wyjścia brane jest pojęcie, koncept, jakiego dotyczy dana grupa frazeologizmów, np.: z pojęciem lenistwa - lijenosti związane są przykłady: len kej crna zemlja, mrtvo puhalo 'lijena osoba', kej bik na gmajni, kej trut, neki se ni vruč vode napil, delat kej u masnoj robici 'ne priviknuti fizičkom poslu'; pracowitość, sumienność, ciężka praca - marljivost: delat kej crnac, kej crv, kej konj, kej mašina, kej sivonja, Katica za sve, imat zlatne ruke. To ciekawe ujecie pokazuje, jakie aspekty pojęciowe i w jakim wymiarze realizuje frazeologia dialektalna.

Zadaniem badań frazeologii dialektalnej jest nie tylko kodyfikacja i uchronienie od zapomnienia zasobów lokalnych dialektów chorwackich. Ważnym celem tych badań jest zwrócenie uwagi na językową konwergencję frazemów na różnych płaszczyznach, co akcentuje m.in. M. Matešić w powyżej cytowanym artykule. W grupie frazeologizmów dialektalnych wyodrębnić można: 1. frazeologizmy typowe tylko dla części omawianego obszaru dialektalnego, np.: projt u Krš́ 2 . frazemy występujące na terenie całego obszaru danego dialektu, np.: tvrd kej bat; 3. frazemy, które w zmienionej formie znane są $\mathrm{w}$ innych dialektach i w języku standardowym, np.: pala je kemu sikera u med; 4. frazeologizmy podlegające konwergencji międzyjęzykowej, np.: gledat kroz prsti, bit na vrh jezika (Matešić 2006, 59).

Frazeologia historyczna. Frazeologia historyczna w Chorwacji nie może się poszczycić tak bogatymi osiągnięciami jak frazeologia dialektalna, co zbieżne jest $\mathrm{z}$ sytuacją w polskim językoznawstwie. Diachronia we frazeologii nie jest chętnie wybieraną dyscypliną ze względu na wiele niesprzyjających czynników: niekompletna baza materiałowa, brak dłuższych tradycji badawczych i wynikają- 
cych stąd podstaw metodologiczno-teoretycznych, trudności wynikające z braku kompetencji językowych w stosunku do materiału historycznego. W przypadku chorwackim dodatkową komplikacją może być zróżnicowanie dialektyczne. Właśnie na przykładzie Chorwacji można zauważyć wzajemną zbieżność i zależność badań historycznych i dialektalnych, gdyż w przeszłości wszystkie trzy dialekty pełniły tam funkcję języków literackich - dialekt czakawski w XVI w., sztokawszczyzna dubrownicka w XVII, a kajkawski w XVIII w. Dlatego też w przypadku tych ziem nie da się rozgraniczyć do końca badań dialektalnych od historycznych, zwłaszcza w dziedzinie leksyki, frazeologii.

Frazeologią historyczną w Chorwacji zajmują się głównie: Liljana Kolenić, Nada Vajs, Vesna Zečević, Antica Menac, Milan Moguš. Obecnie najaktywniej na tym polu działa prof. L. Kolenić z uniwersytetu w Osijeku, niemniej jednak prekursorami badań frazeologii historycznej byli M. Moguš (O Marulićevoj frazeologii 1990, 1994) oraz A. Menac, która jest autorką kilku historycznojęzykowych artykułów na temat frazeologii w starszej literaturze chorwackiej, m.in: Frazeolgija Gundulićeva Osmana, Frazeologija Hektorovićeva Ribanja i ribarskog prigovaranja, Frazeologija Mažuranićeve Smrti Smail-age Čengicia, oraz poświęconych frazeologizmom zawartym w starszych słownikach chorwackich: Frazeologija u različitim tipovima jednojezičnih hrvatskih rječnika, Frazemi u Šulekovu Rječniku znanstvenog nazivlja (por. Menac 2007).

Zauważalną cechą badań frazeologii historycznej jest jej dwutorowość, polegająca na analizie historycznego materiału literackiego - z dzieł dawnych pisarzy, pieśni, kronik - oraz leksykalnego - ze starszych słowników języka chorwackiego, od XVII w. począwszy. Cechą charakterystyczną chorwackiego materiału leksykalnego jest znaczna obecność wyrażeń frazeologicznych nawet w najstarszych słownikach - u Belostenca, Habdelicia - a przede wszystkim wyodrębnianie frazeologizmów, próba eksplikacji, a nawet klasyfikacji pośród całości materiału, choć przecież frazeologia, jako dyscyplina, nie była wtedy znana.

Warte podkreślenia w tej kategorii prac frazeologicznych są osiągnięcia L. Kolenić - autorki dwóch monografii poświęconych frazeologii historycznej i historii frazeologii: Riječ o riječima. Iz hrvatske leksikologije i frazeologije 17. i 18. stoljeća (Osijek 1998); Riječi u svezama. Povijest hrvatske frazeologije (Osijek 2006) ${ }^{3}$. Pierwsza z monografii, oprócz części teoretycznej zawiera obszerny słownik frazemów wyekscerpowanych z dzieł literackich z XVII i XVIII wieku - głównie pisarzy slawońskich, bośniackich oraz z Przymorza Chorwackiego,

3 Bibliografia prac L. Kolenić znajduje się na stronie internetowej http://web.ffos.hr/ hrvatski/?id=22 (dostęp: 17.03.2013). 
a także ze słowników Belostenca i Habdelicia, którym to autorka poświęciła wiele uwagi również we wcześniejszych artykułach. Kolenić pokazuje analogie między związkami frazeologicznymi zawartymi w dziełach literackich i słownikach, pochodzących z różnych terenów, mimo istniejących pomiędzy nimi różnic dialektycznych. Zwraca uwagę na powtarzalność pewnych fraz i określeń w języku dzieł starej literatury chorwackiej, co stało się powodem do ich kodyfikacji w słownikach. Stąd wniosek, iż przedmiot badań późniejszej frazeologii jest znacznie starszy niż sama nauka.

Frazeologia kontrastywna. Frazeologia porównawcza $\mathrm{z}$ kolei należy do tych aspektów badań frazeologicznych, które w Chorwacji rozwijają się dość intensywnie. Ponieważ dotyczy badań komparatystycznych materiału z różnych języków, naturalnym jest faktem, że zajmują się nią głównie przedstawiciele filologii obcych. Duży jest udział przedstawicieli filologii słowiańskich różnych specjalności językowych, np.: rusycyści A. Menac, Ž. Fink-Arsovski, A. Hrnjak; poloniści I. Vidović-Bolt i N. Pintarić; bohemiści S. Ribarova, A. Bunk; bułgarystka A. Vasung. Liczne są też chorwackie prace komparatystyczne w zestawieniu z językami o dużej popularności, głównie z językiem angielskim, niemieckim, francuskim, włoskim. Najwcześniej pojawiły się prace komparatystyczne A. Menac dotyczące aspektów porównawczych języka chorwackiego i rosyjskiego, choć autorka dokonuje też szerszej analizy zapożyczeń frazeologicznych z różnych języków: Iz problematike frazeološke sinonimije u hrvatskom i ruskom književnom jeziku, Posuđeni elementi u hrvatskoj i ruskoj frazeologiji, Frazeološki antonimi u europskim jezicima, Zajedničke semantičke grupe u frazeologiji europskih jezika (por. Menac 2007).

Prace porównawcze dotyczą badań w obrębie dwu lub większej liczby języków, a ograniczenie materiału do frazeologizmów konkretyzuje przedmiot analizy. Ta dziedzina badań frazeologicznych, oprócz niewątpliwych wartości poznawczych, posiada także niebagatelną rolę użytkową, gdyż idiomy, nie tylko w języku obcym, ale nawet w rodzimym, należą do najtrudniejszej, zleksykalizowanej, zmetaforyzowanej warstwy językowej, a prace tego typu pokazują podobieństwa i różnice w sferze frazeologii różnych języków. Jest to rodzaj synchronicznej analizy stanu języka, ale często sięgający też do historii, warstwy dialektalnej, stylistycznej. Dlatego też wymaga dużej i kompleksowej wiedzy na temat kultury, tradycji, systemów wartości użytkowników danych języków, co ważne jest przede wszystkim w pracach przekładowych. Często osoby zajmujące się analizą komparatystyczną w dziedzinie frazeologii różnych języków mają też doświadczenia translatorskie.

Zainteresowania frazeologii kontrastywnej są bardzo szerokie. Mają dwutorowy charakter, lecz są ze sobą ściśle związane, mianowicie: naukowa 
analiza porównawcza wybranego materiału i praca leksykograficzna - tworzenie słowników, spisów frazeologizmów porównawczych dwu lub więcej języków. Badania teoretyczne koncentrują się wokół takich zagadnień, jak kategorie semantyczne w aspekcie porównawczym, kategorie pojęciowe, mamy tu wyraźny wpływ lingwistyki kognitywnej. Wśród prac poświęconych idiomom określonych kategorii tematycznych, znaczeniowych warto wymienić kilka prac poświęconych frazeologii zoonimicznej w różnych językach: monografia I. Vidović-Bolt, Životinjski svijet u hrvatskoj i polskoj frazeologii (Zagreb 2011), będąca również słownikiem frazemów zawierających nazwę zwierzęcia; artykuły A. Bunk, M. Opašić, Prilog kontrastivnoj analizi frazema sa zoonimskom sastavnicom u hrvatskome i češkome jeziku (2011), A. Vasung, Frazemi sa sastavnicama pas $i$ mačka $u$ hrvatskom i bugarskom jeziku; prace poświęcone porównaniom w obrębie bardzo różnorodnych typów i kategorii pojęciowych (części ciała, morze, moda, kulinaria, kolory). Problemy na które zwraca się tu szczególną uwagę to: zjawisko ekwiwalencji (całkowita, częściowa lub brak), metaforyczność pojęć u podłoża konceptualizacji frazemów, związek pojęcia z kulturą, tradycją, historią, stereotypem - trudności w przekładzie tak zwanych nacionalnih frazema: provesti se kao Janko na Kosovu, drugo Tursko, i mirna Bosna, vrući krumpir.

Drugim ważnym aspektem frazeologii komparatywnej są prace leksykograficzne - tworzenie słowników dwu lub wielojęzycznych. W dziedzinie frazeologii zapoczątkowały to słowniki: duży, dwutomowy Rusko-hrvatski ili srpski rječnik pod red. A. Menac (1979); Hrvatsko-njemački frazeološki rječnik pod red. J. Matešicia (1988); seria małych słowników dwu- lub trzyjęzycznych w ramach projektu Mali frazeološki rječnici realizowanego w latach osiemdziesiątych pod kierunkiem A. Menac - Menac, Rojs, Hrvatsko-slovenski frazeološki rječnik; Menac, Pintarić, Hrvatsko-poljski frazeološki rječnik; Blaževac, Hrvatsko-francuski frazeološki rječnik; Menac, Trostinska, Hrvatsko-rusko-ukrajinski frazeološki rječnik; Cvjetković, Kurelec, Hrvatsko-novogrčki frazeološki rječnik; Bricko, Salopek: Hrvatsko-grčki frazeološki rječnik; Novaković, Perić, Tajčević, Vratović, Hrvatsko-latinski frazeološki rječnik; Menac, Vučetić, Hrvatsko-talijanski frazeološki rječnik; Menac, Sesar, Kuchar, Hrvatsko-češko-slovački frazeološki rječnik (por. Kovačević 2008,)

W ostatnich latach powstały dwa ważne dla frazeologii porównawczej słowniki idiomów: Hrvatsko-slavenski rječnik predbenih frazema Ž. Fink-Arsovski (2006) oraz długo wyczekiwany, obszerny, zawierający 9000 haseł: Hrvatsko-engleski frazeološki rječnik, D. Vrgoč, Ž. Fink-Arsovski (2008). Pierwszy ze słowników stanowi niezwykle ciekawy projekt od strony materiału. Są to tzw. porównania frazeologiczne, które przedstawione są w dziewięciu językach 
słowiańskich. Językiem wyjściowym jest chorwacki. Przy tworzeniu słownika współpracowała cała grupa slawistów językoznawców różnych specjalności. Przedstawiono 540 frazeologizmów chorwackich z elementem kao i starano się pokazać ich ekwiwalencję w pozostałych językach słowiańskich. Autorzy doszli do interesujących wniosków. Największy stopień ekwiwalencji omawianych pojęć występuje w językach: ukraińskim (517 przykładów), słowackim (503), macedońskim (486), zaś najniższy w słoweńskim (347) i polskim (380).

Słowniki frazeologiczne dwujęzyczne lub wielojęzyczne są niezwykle ważnym elementem lingwistyki praktycznej, nieocenionym zarówno w pracach translatorskich, jak i w komunikacji osób uczących się języków obcych. Jest to na pewno jeden z czynników decydujących o tak intensywnym rozwoju frazeologii porównawczej.

Kognitywne aspekty frazeologii. W najnowszych badaniach frazeologicznych po 2000 r. zaobserwować można charakterystyczny aspekt badawczy, typowy dla lingwistyki kognitywnej - koncentrację na semantyce omawianych pojęć, odwołania do pewnych schematów pojęciowych istniejących w naszym umyśle, do pojęcia kategorii i prototypu również w przypadku idiomów.

Frazeologizmy jako jednostki kondensujące znaczenie doskonale nadają się do analizy kognitywnej, często u ich podłoża znajduje się metafora i metonimia - jako jedne z najważniejszych mechanizmów konceptualizacji naszej wiedzy. Metaforyczność znaczeń, wielu językoznawców uważa za jeden z głównych wyróżników związku frazeologicznego, tak jak i odwoływanie się do naszych skojarzeń pojęciowych. Analizę kognitywną można zastosować do każdego rodzaju materiału frazeologicznego, także starszego lub dialektalnego, co też niektórzy językoznawcy czynią (patrz wyżej: frazeologia dialektalna, Matešić 2006). Jest to możliwe dlatego, że analiza kognitywna nie koncentruje się tylko na aktualnym stanie języka lub wiedzy o świecie, ale sięga do głębszych zasobów naszego umysłu, także odwołując się do przeszłości. Jej celem zresztą było nieoddzielanie synchronii od diachronii, co akurat jest bardzo ważne i celowe również w opisie frazeologizmów, bowiem zdaniem A. Pajdzińskiej: „W opisie frazeologizmów szczególnie trudno jest rozgraniczyć synchronię i diachronię. Jednostka frazeologiczna nigdy nie powstaje od razu, zawsze jest rezultatem stopniowego ustalania się połączenia luźnego. Poza tym swoisty konserwatyzm zasobu frazeologicznego: przechowywanie archaicznych leksemów, znaczeń i modeli syntaktycznych [...] zmusza do łączenia kryteriów opisu" (Pajdzińska 2001, 16).

Analizę kognitywną frazeologizmów odnaleźć można w publikacji A. Hrnjak Putovanje kroz hrvatsku frazeologiju (2009), gdzie autorka odnosi konceptualną metaforę život je putovanje do wyrażeń frazeologicznych; w innych pracach 
na temat metaforycznych znaczeń we frazeologii analizuje metaforę: život je kazalište, pojęcia: piękna, strachu, symbolikę barw. N. Ivanetić w artykule More u frazeologii (2002) wskazuje na wielość mentalnych koncepcji i powiązań metaforycznych prototypowego pojęcia „morze” we frazeologii, m.in. apatia: mrtvo more, bezmyślność, bezcelowość: sipati pijesak u more, bacati sol u more, obojętność: ravno je komu sve do mora, briga nekoga što Mađarska nema mora, śmierć: proliti more krvi.

Działalność leksykograficzna (w obrębie frazeologii języka chorwackiego). Ważnym aspektem współczesnej frazeologii chorwackiej są prace leksykograficzne w celu stworzenia korpusu frazeologicznego języka chorwackiego. W tym względzie frazeologia chorwacka ma już pewne osiągnięcia.

Najważniejszymi słownikami frazeologicznymi języka chorwackiego są: powstały jeszcze w czasach Jugosławii wspominany wcześniej J. Matešicia Frazeološki rječnik hrvatskoga ili srpskoga jezika (1982); Hrvatski frazeološki rječnik A. Menac, Ž. Fink-Arsovski, R. Venturina (2003). Słownik Matešicia jest obszerniejszy, zawiera 12000 haseł, przy czym niektóre frazemy pojawiają się wielokrotnie w formie odsyłaczy i w efekcie liczba jednostek podlega zwielokrotnieniu nawet do 30000 (Tafra 2005, 50). Słownik zawiera wiele przysłów i powiedzeń, których późniejszy leksykon nie zalicza do frazeologizmów. Jak już wspomniano, sporo materiału w tym słowniku pochodzi z języka serbskiego. Hrvatski frazeološki rječnik jest znacznie mniejszy - zawiera 2258 jednostek frazeologicznych, co spowodowane jest wieloma czynnikami. Słownik ten jest pozbawiony wielu archaicznych i dialektalnych form. Celem autorów było pokazanie współczesnego, używanego przez społeczeństwo języka z okresu po 1945 r. Autorzy weryfikowali wybrany materiał, opierając się głównie na wynikach ankiet wśród młodszej populacji - studentów trzech różnych ośrodków akademickich (Zagrzeb, Zadar, Mostar), co jak wiadomo, mogło mieć duży wpływ na zawartość słownika, gdyż młodsze pokolenie raczej nie wykazuje się szczególną skłonnością do znajomości i używania frazeologizmów (Menac, Fink 2001, 343). Jest tu z kolei wiele kolokwializmów, internacjonalizmów z najnowszej warstwy języka. Oba słowniki wzajemnie się uzupełniają, gdyż słownik późniejszy miał być w zamyśle autorów rodzajem podręcznego słownika dla wszystkich.

Warto też wspomnieć o materiale leksykograficznym zawartym w obszernym dziele Bibliografija hrvatske frazeologije, Ž. Fink-Arsovski, A. Hrnjak, B. Kovačević (2010). Monografia zawiera bogaty indeks związków frazeologicznych (714 stron), który w opinii wielu językoznawców można uważać za słownik, mimo iż nie spełnia jego wszystkich kryteriów. Autorki wykorzystują zasadę morfologiczną klasyfikacji frazemów, podobnie jak w słownikach frazeologicznych. 
Różnica polega na braku eksplikacji znaczeniowej. Są jednak odniesienia do zawartych w pierwszej części bibliografii tekstów, w których omawiany jest dany przykład (Kramarić 2011; Opašić 2011).

\section{Podsumowanie}

Objętość wyżej wspomnianej Bibliografii frazeologii chorwackiej (prawie 1000 stron, licząc razem $z$ indeksem frazemów) najlepiej świadczy o rozmiarach prac badawczych $w$ dziedzinie frazeologii w Chorwacji w ciągu ostatnich czterdziestu lat - od pierwszych prac teoretyczno-popularyzatorskich z lat 70 . do czasów współczesnych. Powyższe rozważania nie mają na celu oceny osiągnięć tej dziedziny nauki ani też nie roszczą sobie pretensji do pełnej analizy poczynań badawczych licznej i stale powiększającej się grupy chorwackich badaczy frazeologii, gdyż nie byłoby to możliwe w tak skondensowanej formie artykułu. Wielu osób, prac i szczegółowych zainteresowań badawczych nie udało się w prezentacji przedstawić. Celem analizy było zarysowanie problemów, stanowisk, przedstawienie pewnych dyscyplin znajdujących swoje miejsce w ramach badań frazeologicznych, jak: frazeologia dialektologiczna, historyczna, współczesnego języka w różnych jego formach, frazeologia kontrastywna, działalność leksykograficzna.

Ważnym aspektem frazeologii jest to, że nauka ta cieszy się sporym zainteresowaniem szerokiego społeczeństwa, nie jest li tylko przedmiotem badań akademickich. Świadczą o tym dyskusje na tematy związane z frazeologią na forach internetowych, porady specjalistów w prasie na temat znaczenia i etymologii frazeologizmów, np. w czasopiśmie „Vijenac” (np.: Ima ih kao Kineza; Lewis 2007, nr 359; Pala mi je sjekira u med; Opačić 2008, nr 362) ${ }^{4}$, co służy popularyzacji tej nauki i przyczynia się do wzrostu wiedzy na jej temat.

\section{Literatura}

Chlebda W., 1991, Elementy frazematyki, Opole.

EJO 1995 - Encyklopedia językoznawstwa ogólnego, hasło: frazeologia, lingwistyka kognitywna, red. K. Polański, Wrocław.

${ }^{4}$ Czasopisma dostępne on-line: http://www.matica.hr/Vijenac/vijenac362.nsf/AllWebDocs/ Pala_mi_je_sjekira_u_med, http://www.matica.hr/Vijenac/vijenac359.nsf/AllWebDocs/ Ima_ih_kao_Kineza (dostęp dnia: 19.03.2013). 
Filaković S., 2008, Frazeologija u djelima Ivane Brlić-Mažuranić, „Život i škola” 19, s. 37-64. Fink-A rsovski Ž., 2002, Poredbena frazeologija - pogled izvana i iznutra, Zagreb.

Fink-A r sovski Ž., 2007, rec. Antica Menac, Hrvatska frazeologija (Zagreb, Knjigra, svibanj 2007, 270 str.), „Suvremena lingvistika” 64, s. 228-231.

Fink-Arsovski Ž., Hrnjak A., Kovačević B., 2010, Bibliografija hrvatske frazeologije i CD s popisom frazema analiziranih u znanstvenim i stručnim radovima, Zagreb.

Hrnjak A., 2009, Putovanje kroz hrvatsku frazeologiju, „Südslavistik on-line” 1, s. 197-206, http://www.academia.edu/1993750/U_petoj_brzini_kroz_frazeologiju.

Iva netić N., 2002, More u frazeologiji, „Fluminensia” 14, 1, s. 67-84.

Jóź wiak-Dąd ela A., 2006, Historia i wybrane aspekty badań nad frazeologią, „Studia Neofilologiczne. Prace Naukowe AJD” V, s. 17-26.

Kolenić L., 1998, Riječ o riječima. Iz hrvatske leksikologije i frazeologije 17. i 18. stoljeća, Osijek.

Kolenić L., 2006, Riječi u svezama. Povijest hrvatske frazeologije, Osijek.

Kovačević B., 2008, Dugo iščekivan frazeološki dvujezičnik, „Rasprave Insituta hrvatskog jezika" 34, s. 463-519.

Kramarić M., 2011, Blago jezika hrvatskoga, „Rasprave Instituta hrvatskog jezika” 37, 1, s. 261-299.

Lewicki A. M., 1974, Aparat pojęciowy frazeologii, [w:] Z badań nad literaturą i językiem, red. W. Ludorowski, J. Magnuszewski, Warszawa, s. 135-151.

Maln a r M., 2011, Somatska frazeologija čabarskih govora, „Rasprave Zavoda za hrvatski jezik i jezikoslovlje" 37, 1, s. 101-119.

Matešić J., 1978., O poredbenom frazemu u hrvatskom jeziku, „Filologija” 8, s. 211-217.

Matešić J., 1982., Frazeološki rječnik hrvatskoga ili srpskoga jezika, Zagreb.

Matešić J., 1988, O problemu dijalektalne frazeologije, [w:] „Z problemów frazeologii polskiej i słowiańskiej” IV, red. M. B a saj, Wrocław, s. 53-57.

Matešić M., 2006, Frazeologija mjesnog govora Vrbovskog, „Fluminensia” 18, 2, s. 37-81.

Matulina Z., 2005, Paremija u hrvatskom i njemačkom televizijskom programu, „Fluminensia" 17,2 , s. 67-84.

Menac A., 1970/71, O strukturi frazeologizama, „Jezik” 1, s. 1-4.

Menac A., Fink Ž., 2001, Odabir frazema za Priručni rječnik hrvatskoga jezika (rezultati ankete), [w:] Frazeologia słowiańska, red. M. Balowski, W. Chlebda, Opole, s. 341-354.

Menac A., Fink-Arsovski Ž., Venturin R., 2003, Hrvatski frazeološki rječnik, Zagreb.

Menac A., 2007, Hrvatska frazeologija, Zagreb.

Menac-Mihalić M., 2011, Iz kajkavske frazeologije, „Rasprave Zavoda za hrvatski jezik i jezikoslovlje" 37, 2, s. 479-491.

Muhvić-Dimanovski V., 1992, Neki problemi prezentacije frazeologizama u frazeološkim i općim rječnicima, „Filologija” 20-21, s. 323-329.

Nowakowska A., 2005, Świat roślin w polskiej frazeologii, Wrocław.

Opa šić M., 2011, Od A do Ž o istraživanjima hrvatske frazeologije, „Fluminensia” 23, 2, s. $188-190$. 
Pajdzińska A., 2001, O znaczeniu związku frazeologicznego (raz jeszcze), [w:] „Problemy frazeologii europejskiej IV”, red. A. M. Lewicki, Lublin, s. 12-18.

Tafra B., 2005, Frazeološki izazovi, „Jezik” 52, s. 48-61.

Vidović-Bolt I., 2006, Frazeologia w chorwacko-polskich leksykograficznych badaniach kontrastywnych, [w:] Literatura, kultura i język polski w kontekstach i kontaktach światowych, red. M. Czermińska, K. Meller, P. Fliciński, Poznań, s. 825-836.

Vidović-Bolt I., 2011, Životinjski svijet u hrvatskoj i poljskoj frazeologiji, Zagreb.

Vulić S., 2003, Leksikografska obrada frazema u budućem velikom sintetskom rječniku izvornih čakavskih govora, „Fluminensia” 15, 1, s. 43-56.

\section{Research interests and progression of Croatian phraseology}

\section{(Summary)}

The article examines the progression of phraseology research in Croatia. First researches started in the Nineteen Seventies. A. Menac, J. Matešić, Ž. Fink-Arsovski made the largest contribution to the Croatian phraseology as authors of phrasebooks and many dissertations. Nowadays studies are conducted by the members of Phraseology School of Zagreb. The article shows their achievements from creation to the present day in the following areas: dialect phraseology, history of phraseology, theory of (theoretical) phraseology, comparative phraseology, synchronous phraseology and lexicography. 